\title{
E-CRM on the Relationships Quality and Its Consequences: Evidence from Iranian Private Banks
}

\author{
Mohammad Javad Taghipourian ${ }^{1 *} \quad$ Sahar Hatami $^{2}$ \\ 1. Department of management, Islamic Azad University, Chalous branch, Chalous, Iran. \\ 2.Department of business management, A Non-Profit,Non-Govermental Educational Institute of Tabarestan, \\ Chalous,Iran
}

\begin{abstract}
The importance and urgency of the subject Low rates of e-services and research in the department of Electronical Customer Relationship Management (E-CRM) in banking system of the country, particularly is from the perspective of clients, the research investigated E-CRM on the relationships quality and it's consequences: evidence from Iranian the private banks, Therefore a questionnaire adapted from George et all and Abdallah scale be determined in the statistical community between private's bank electronic customers of 388 people, after collecting information and data, the questionnaire designed by Likert scale and obtained by use of random sampling, and evaluated and analyzed by structural equations model method and LIZREL software. Data results show that E-CRM had a positive and meaningful effect on the relationships quality and the consequences of customers that include 7 component such as: communication channels, the overall quality of communication, confidence, satisfaction, loyalty, maintenance and the tendency to compromise.The results of research was confirmed the impact and importance of E-CRM on the quality dimensions and relationships consequences with customers like The satisfaction, loyalty and maintenance.
\end{abstract}

Keywords: Customer Relationship Management, Electronical Customer, Relationships Quality.

DOI: $10.7176 / \mathrm{EJBM} / 11-25-01$

Publication date:September $30^{\text {th }} 2019$

\section{Introduction}

E-CRM is the latest example of customer relationship management in the world. When an organization from a centralized human body changes to another organization, it focuses on multiple electronic contact points, including telephone, fax, email, web, and more. The ability to create management and customer relationships increases dramatically, as a result, business and service of the non-computerized management of CRM customer relationships changes to electronic channels. This method is usually called E-CRM. Creating long-term relationships with customers is usually considered as a key factor in profitability in a highly dynamic marketplace.

The quality and importance of E-CRM is one of the first trick initiatives in today's industry, especially banks, and is one of the major marketing partners in the electronic world. As E-CRM topics are not well known in the banking industry of Iran, exploratory qualitative work is a useful and necessary step in achieving a better understanding. The implementation of E-CRM has a direct and indirect impact on the quality and consequence of electronic customers relationship with the bank.

Philip Kotler views E-CRM as a part of e-business which explains use of tools and platforms for running companies and enables them to serve their customers more rapidly and widely with lower costs and customizes products and services Kotler (2014). Furthermore, E-CRM is a marketing, sales and integrated online services strategy which plays role in identification, achieving and maintenance customers as the greatest capital of the company Al-Badawi (2014).

E-CRM is defined as 'technology-centered' relationship marketing and ensuing advantages, incorporating traditional customer relationship management (CRM) tactics and e-business market place applications used by an organization to maintain customer relations (Dubihlela and Khosa, 2014; Harrigan, Ramsey and Ibbotson, 2012; Keshvari, 2012; KimSoon and Zulkifli, 2012; Salehi et al., 2015).

Considering the special importance has electronical relationship management with customers for banks and service providers, the main goal of this research is: The study of the application of electronic relationship management system with customers in the banking industry, from the perspective of bank customers and providing practical solutions. To run it better and

1.Determining the Effects of E-CRM on the Bank's Customers' Relationships and the Perspectives of Customers in Banks.

2. Determining the Benefits of E-CRM Deployment for Bank Customers in Interacting with Banks.

3. Determining the relationships quality and the consequences in relation to the implementation of E-CRM from the point of view of bank customers. 


\section{Literature review \\ 1.1 E-CRM}

The term CRM was created with its current concept since the 1990s and developed in the form of a business strategy to select and manage the most valuable communications with customers. Customer relationship management requires a customer-centric philosophy and a culture of supporting effective marketing, sales and after-sales services in the organization. Customer-centric culture is based on a simple concept of one-to-one communication between customers and vendors. This attitude looks to each customer in the eyes of a person with demands, purchases, and needs.

By using CRM, customer relationship with the company and its needs are analyzed. Customer relationship management is in fact a process for collecting and integrating information for their effective and targeted exploitation. This information can be related to customers, sales, effective marketing, sensitivity and market needs (Elahi and Heidari, 2005). Based on the research of Mousavian and Jalili (2017)," Investigation of Relationship between E-Banking Industry Risks and Electronic Customer Relationship Management (E-CRM)" we have CRM as following:

1. Relationship CRM: it is considered for creation of online communications, development of transactions and customized inter-firm services and also transactions among businesses and their customers and suppliers and distribution channels and customers.

2. Operational CRM: it is considered for developing customer services, online marketing, sales automation and so on. This is in fact automation of CRM processes-customer facing-which manages customers' contacts with marketing and sales.

3. Analytical CRM: it is considered for creation of warehouses, development of communication, analysis of data and so on which makes use of customers' data for establishment of a useful relationship between a business and customers. This analysis contributes to modeling and establishment of a personalized relationship. Because this paper is concentrated on E-CRM, we deal with it in more detail.

The difference between CRM and E-CRM is that the new CRM, or the same E-CRM, is based on CRM, but more emphasis is placed on individualization, direct marketing technologies for sales and the provision of distinct services to small market segments. E-CRM makes this possible for customers, By providing more effective communication with the company, it will further reveal its potential as a client so that both the company and the client benefit from this relationship. Also, E-CRM is based on the CRM platform, with a double focus on segmentation technologies, customer information analysis, multichannel relationship, one-to-one interactions, and service delivery to specific sectors of the market. The use of information technology in customer relationship management led to the formation of the concept of E-CRM. As a result, the use of IT capabilities made it possible for customers to produce their own proprietary products. It should be said that new technologies, especially the Internet, are the "E" factor in E-CRM. For example, with E-CRM, you can :

-implement a level of personalization that was impossible with CRM. One of the advantages of E-CRM is to facilitate the provision of goods and custom service to each customer.

-Reacted faster than the customer in channels that are completely different from what was in CRM.

-Tracking the behavioral trends of each customer, as it was not possible in E-CRM.

-Increased customer empowerment, that's less in CRM.

In order to reduce costs, we can The biggest goal of E-CRM is to improve the customer retention process. Because customer retention can reduce costs. The quality and other consequences of the following can be cited for customer relationships management:

Increase customer satisfaction. Increase competitive ability. Meet customers' needs and meet customer demand. Establish and implement an active marketing strategy based on customer relationship. Attracting and retaining the best of our customers, Increasing revenue by reducing customer's escape and loyalty.

E-CRM features can be part of CRM, CRM improvement, technology facilitation, use of electronic channels, use of digital channels, electronic commerce, Internet, mobile, wireless, TV, email, chat and interaction, Internet marketing, multichannel communication, processing automation, Internet data, service and order generation, sales, marketing, services, electronic messaging, intelligent search engine, online shopping, online browsing. 
Table (1): Concept and Definition of CRM

\begin{tabular}{|l|l|}
\hline Researchers & Concept and Definition of CRM \\
\hline $\begin{array}{l}\text { Khalifa \& Shen (2005), Barnes(2001), } \\
\text { Brown(2000), Foss \& Slone(2002), }\end{array}$ & $\begin{array}{l}\text { Interactions between customers who are more informed and more } \\
\text { need, they need more attention, and companies that pay more attention } \\
\text { to the customer and have a strong interest in building closer } \\
\text { relationships with their customers and interacting with them. }\end{array}$ \\
\hline Swift (2001) & $\begin{array}{l}\text { An organizational approach to understanding and influencing } \\
\text { customer behavior through meaningful relationships to improve } \\
\text { customer orientation, customer retention, customer loyalty and } \\
\text { customer profitability. }\end{array}$ \\
\hline $\begin{array}{l}\text { Anton \& Hoeck(2002), Chalmeta } \\
\text { (2006), Dyche (2001) }\end{array}$ & $\begin{array}{l}\text { A customer-centric commercial approach that describes the increase } \\
\text { in customer value and the right practices by which valuable customers } \\
\text { remain loyal. }\end{array}$ \\
\hline Lindgreen \& Antioco (2005) & $\begin{array}{l}\text { The way to rely on the 5-step approach. Five essential things that need } \\
\text { to be controlled by companies that want to enforce relationships with } \\
\text { their customers: segmentation, information networking, algorithms, IT } \\
\text { systems and sales, and customer support . }\end{array}$ \\
\hline $\begin{array}{l}\text { Ginsaid(2003),Sing } \\
\text { viam(2005),Protiar\&shis(2001) }\end{array}$ & $\begin{array}{l}\text { Applying the trick of information, processes, technology and } \\
\text { individuals, a way to compete It brings a lot of pressure to an } \\
\text { organization and has a positive impact on organizational performance. }\end{array}$ \\
\hline Jackson (1985) & $\begin{array}{l}\text { Marketing that works in the long-term relationships with individual } \\
\text { accounts, innovation, development and improvement of customer } \\
\text { personal relationships with customers and buyers who maximize the } \\
\text { overall value of customer life. }\end{array}$ \\
\hline Anton \& Hoeck (2002) & $\begin{array}{l}\text { A way to complete and flawlessly complete different activities to } \\
\text { predict, understand, and meet customer needs. }\end{array}$ \\
\hline Singh(2002) & $\begin{array}{l}\text { The main goal is to attract and retain customers, which leads to } \\
\text { substantial financial benefits. }\end{array}$ \\
\hline
\end{tabular}

\subsection{The quality of the relationship and the consequences of the customer relationship :}

Losing customers negatively affects the market share and the profits of companies, especially banks. Several studies show that when the customer leaves the service provider and to another provider The loss of additional profits, initial investment costs on the customer, and additional costs of customer retrieval will be replaced. For the above reasons, as well as the competition, the discussion about customer withdrawal is necessary. (Colgate and Hutch 2001). The impact of e-CRM in the banking sector and the good preservation of CRM systems can be a long-term relationship make customers more productive and profitable. Banks must recognize the strategic role of CRM and the diversity and variety of needs of different customers. In addition, professional staff must be hired by the banks to work against the complexity of the system and an effective way. Gupta (2013). Focusing on highlighting the critical role of IT in enhancing customer engagement experience, where E-CRM content is similar to CRM. The banking industry uses IT to facilitate the use of information, customer profiles, flow control, cost reduction, and maintenance of partnerships. Technologies, customers and processes three

The components that ensure the success of banking operations in this constantly changing environment. E$\mathrm{CRM}$ is the most important word in business today and is perceived as one of the most effective tools in the banking sector. So banks are struggling to expand their core customers. Singh and Cyrus (2014). Many companies have combined the concepts of CRM and knowledge management to better serve their customers and make use of such information effective. Others consider e-CRM as an Internet banking app and they are researching on this perspective Mousavian and Jalili (2017).

(Gonaris et al. 2003) have done research on the quality of banking services as a precondition for the quality of perceived services: an exploratory study in the banking industry, the result of this study has examined the factors affecting customer perceptions about banks' quality. And identify. Types of quality are: system quality, quality of information and quality of service.

\subsection{1 communication channels}

respond quickly to customers' requests and supporting them (Alagheband 2006).

\subsubsection{Relationship Quality}

Define communication quality as a customer's understanding of how to estimate expectations, forecasts, goals, and desires related to this whole relationship. This definition is based on the views of Rolow and Miller (1987), Zeitamel and Crosby (1981). Henning-Thurau \& Klee noted in 1997 that the quality of the relationship can be identified as the level of proper estimation of customer needs in this regard. As a result, this overall impression is 
formed by the fact that a customer has a complete relationship with a business firm It takes note of various deals. The quality of the relationship involves several key elements that express the overall nature of the relationship between companies and their customers. The main structures of the relationship quality As a result, the three most frequently identified structures are: Confidence, Satisfaction and Commitment .

\subsubsection{Confidence}

Everything that can provide satisfaction and customer satisfaction. (Rezaian 1387). Confidence effects on the stability of the relationship and the overall quality of the relationship. Gröners pointed out in 1990 that it is important to ensure that high-quality relationships are created.

\subsubsection{Satisfaction}

Satisfaction is a positive feeling that occurs in any person after the use of the goods or the receipt of services, if the goods and services received by the customer meet his expectations, he will feel satisfied if the level of service and the commodity is higher than the expectations of the customer, it will lead to dissatisfaction. (Rezaian 1387). Ostbrock and Grownorz (1994) defined customer satisfaction as a cognitive and emotional customer assessment based on their personal experiences across service flows in this regard.

\subsection{5 loyalty, Maintenance, the tendency to compromise}

E-CRM and customer loyalty. The advent of new technologies has led to a shift from CRM to E-CRM, and with increasing global penetration of the internet, e-CRM has become a more popular communication tool and relationship-building platform (Lam et al. 2013). Organizations, therefore, are keen to deploy different types of eCRM strategies to attract, maintain, and enhance customer relationships, which contribute to loyalty and the organization's success (Chess Media Group and Lieberman, 2010; Yun and Good, 2007). However, relationship management is an initiative that requires commitment, strategic CRM tenets and a correct mindset in order for it to succeed (Govender, 2004). Tanveer (2009) postulates that e-CRM infrastructure provides support to valuable customers to remain loyal, since information stored in the e-CRM database assists an organization to look at the actual cost of attracting and retaining customers. The firm can also access new international customers and seize valuable data essential to the firm's competitiveness and market share (Harrigan, Ramsey and Ibbotson, 2009). Azila and Noor (2011) assert that the association between e-CRM and customer loyalty means that the more customers are satisfied, they repurchase and spread positive word-of-mouth about the service and the provider, which tends to result in longer relationships, trust in, and commitment to the service provider. As such, loyalty will continue to play crucial roles in the organization's competitiveness and profitability (Rahman, 2006). This is supported by some researchers (Gorondutse, Hilman and Nasidi, 2014; Hayes, 2008; Khan and Fasih, 2014; Olupot and Kituyi, 2013) who have suggested that e-CRM impacts on loyalty.

\section{Theoretical framework (model development)}

Zarean (2009) In his thesis entitled "Investigating the Role of Information Technology in the Establishment of ECRM" (E-CRM), concluded that the information technology in CRM was used to evolve into E-CRM. In this way E-CRM does not market traditional marketing, but empowers it. One of these enablers is the IT tools that marketers can use to develop an online technology.

Shams (2006) concluded in his thesis titled "Electronical Customers Relationship Management, the Management Relationship Bridge for Business and Information Technology (ICT)" concluded that in today's competitive environment, organizations need to maintain their valuable customers in order to maintain competition. The method that can be used to reach customer loyalty is to provide them with personalized service. CRM now provides the customer with two types of services. Customer relationship management is a comprehensive approach that ensures to increase relationship with all customers. These customers include the Internet or electronic customers, members of distribution channels, and service providers.

Knowing each customer through the techniques of data warehousing and customer business strategy helps the organization actively sell more products and services to maintenance a good and loyal customer.

Moezi (2012) in his thesis titled "Correlation between the determinants of electronic customer relationship management system (E-CRM) and customer satisfaction in Golsar Fars sanity" From this research, Golsar Fars Company's decision makers have the ability to determine the correlation between the elements shown in the research framework and make more informed decisions for the future of the E-CRM system of the company, and, by examining the changes in each of the model variables, changing the rest of the variable. It is a promising signal that there is a positive and reliable correlation between (information quality) and (customer system performance and customer satisfaction). This point can be gleaned from Golsar Fars Company to further enhance the E-CRM system of the company and to find out A higher level of customer satisfaction What was the quality of investment information, as a more general conclusion, it can be said that by investing in E-CRM information and services, it could be expected to enhance the performance of a well-considered organization.

Tanweer (2009), in his thesis titled "Electronic Customer Relationship Management (CMS) in Online Banking", aims to investigate how to Electronic Customer Relationship Management with banks using this tool, E-CRM, and how successful implementation this tool was in banks. A qualitative survey on both banks, one in 
Sweden and the other in Denmark, took a look at internal E-CRM measures. Results showed that banks use ECRM for customer-friendly bulk, customer status descriptions, self-determination, interactions with one-to-one automated wafer The flow of financial data, such as collateral, which ultimately leads to a decline in revenue No performance and increase customer loyalty and more profitability.Also, employee training and customer feedback are considered key pillars of the successful implementation of E-CRM.

Sivares (2011) and his colleagues in a study entitled "The Impact of E-CRM (E-CRM) on the Quality and Consequences of Customer-Bank Relations" in Thailand, concluded that: a field study A complete survey of 684 Customers of Thai Business Banks. A special service pattern and a model of quality and relevance were created, verified and verified. The results analysis using Structural Equation Modeling (SEM) showed that the implementation of E-CRM in terms of statistics has a significant positive relationship with service features for the customer and the quality and outcome of bank-customer relations, as well as indirect impact on the quality and the consequence of the relationship through the service features for customers.

Eric \& et all (2017) In his study titled "The relationship between e-CRM and customer loyalty: a Kenyan Commercial Bank case study" They obtained the following results: Since customer loyalty is key, especially in the highly competitive commercial banking environment, this article evaluated the effects of features of electronic customer relationship management (e-CRM) on customer loyalty. Using a cross-sectional survey design, data were collected from a convenience sample of customers of a major international Kenyan bank using self-administered questionnaires. The findings based on correlation and multiple regression analyses, revealed that pre-service, during (the) service and post transactional e-CRM features have a positive and significant relationship with loyalty, and that the pre-service and during the service features significantly predict loyalty. Thus, enhancing e-CRM practices could be a strategic competitive tool to impact the banks' relationship with their customers.

Farooqi \&Khalid (2017) ) In his study titled" Effectiveness of e-CRM in Commercial Banks: Banker's Perspective" They obtained the following results: The e-CRM is perceived as one of the effective tool in the corporate sectors. This tool serves the customers in better way, retain valuable customers and enhance analytical capabilities of an organization. In today's competitive and technological era, commercial banks require to take necessary initiative on e-CRM to better optimize the values of customer relationship, coordinate marketing activities, and effective marketing and business by exploiting various information technology tools. In addition, eCRM focuses on improving customer relationship and earning a large share of customer's business through consistent measurement, assessment and actionable customer-contact strategies. In this article, we have analyzed effectiveness of e-CRM in commercial bank from the perspective of bankers. We collected bankers' data from four commercial banks such as Oriental Bank of Commerce, HDFC, Union Bank of India and HSBC, and effectiveness of e-CRM in these banks has been analyzed. Based on different case analysis, we suggested necessary recommendations for bankers.

Mousavian \& Jalili Ghasbeh (2017) ) In his study titled” Investigation of Relationship between E-Banking Industry Risks and Electronic

Customer Relationship Management (E-CRM)" They obtained the following results: The advancement in ICT has forced banks into adopting electronic customer relationship management (E-CRM) to improve the relationship with customers in order to increase profits, achieve customer satisfaction and loyalty. The present research investigates the risks perceived by customers who have made purchases from bank websites and their relationships with relational dimension have been specified. In terms of goal, this is an applied study and in terms of data gathering method, it is a descriptive survey. Moreover, it is a correlation study in terms of relationship between variables. Statistical population of the study includes customers who use bank websites in Guilan province. Reliability and validity of the questionnaire was also investigated and confirmed. The questionnaires were distributed among 400 customers and finally 384 questionnaires were analyzed using correlation coefficient in SPSS and LISREL software packages. The results revealed that all perceived risks which were studied have relationship with customers' use of websites and successfulness of relational dimension of E-CRM. A negative beta coefficient demonstrated a negative relationship between customers' perceived risks and usage and successfulness of relational dimension of E-CRM.

According to the mentioned materials from past research, the independent variable of E-CRM is expected to have a positive and significant relationship with the degree of dependence variable of the quality and the consequence of customer relationships. Therefore, the conceptual model of the research is represented by the figure (1). 


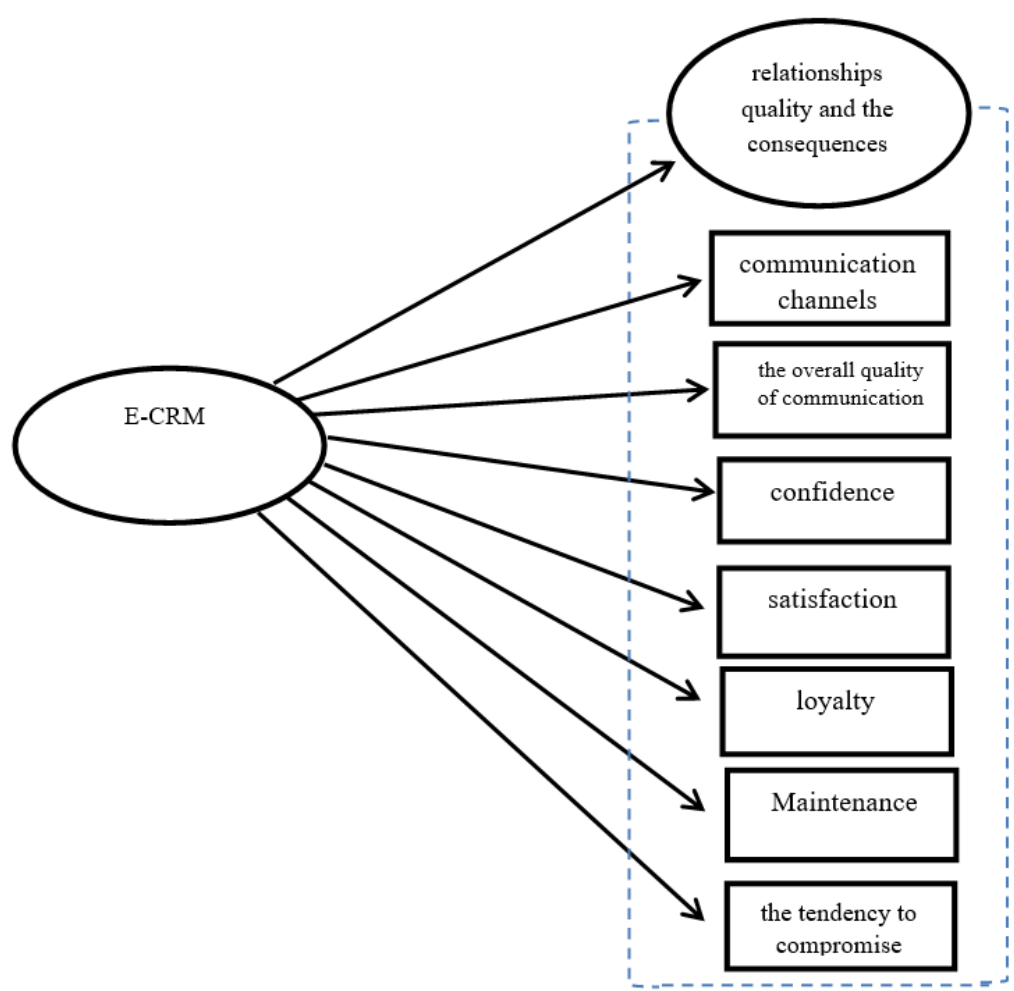

Fig. 1 :The conceptual model of the study

\section{3 .Methodology of research}

This research is considered to be an applied research in terms of its purpose. Based on the method of this research, it is a descriptive one, on the other hand, because we want to choose a sample from the subjects of research and the main tool for collecting data is distributed among the statistical sample and collected, this research is descriptive-correlation type .

In this research, the statistical population of all customers and users of electronic banking that have electronic communication with Private Bank Branches of Private Bank Branch in Tehran have been used. In this research, a simple random sampling method was used for sampling, and the sample size According to the statistical society are 388 people.

A questionnaire was used for this study. In this way, dimensions of E-CRM, quality and consequence of customer relationships are derived from the questionnaire of George \& et all (2011) and Abdallah (2015).

Table (2): Specifications of the items and the variables of the questionnaire

\begin{tabular}{|c|l|c|r|}
\hline Row & \multicolumn{1}{|c|}{ variable } & Number of items & \multicolumn{1}{|c|}{ Source } \\
\hline 1 & Customer communication channels & 6 & George \& et all 2011 \\
\hline 2 & the overall quality of communication & 6 & George \& et all 2011 \\
\hline 3 & \multicolumn{1}{|c|}{ Customer confidence } & 7 & George \& et all 2011 \\
\hline 4 & Customer satisfaction & 6 & George \& et all 2011 \\
\hline 5 & Customer loyalty & 5 & Abdallah 2015 \\
\hline 6 & Customer Maintenance & 5 & Abdallah 2015 \\
\hline 7 & the tendency to compromise & 5 & Abdallah 2015 \\
\hline
\end{tabular}

In this research, the questionnaire consists of 40 questions, $15 \%$ of sample women and $85 \%$ of men. The statistical population of the study was $46.9 \%$ in the age group of 25 to 35 years old. In terms of education, the majority of sample people have undergraduate studies. Respondents based on Internet access, mobile bank 39.9 and SMS Bank, are 35.7 .

To assess the validity of the confirmatory factor analysis using the LISREL software and to assess the reliability of Cronbach's alpha with the help of the SPSS software The result shows the appropriate validity and reliability of the questionnaire, summarized in Table (3). 
Table 3: Summary of Validity Results (Standard Factor Loading of Factor Analysis) and Reliability (Cronbach's Alpha) Questionnaire

\begin{tabular}{|c|c|c|c|c|}
\hline dimensions & variable & Item & $\begin{array}{l}\text { Factor } \\
\text { loading }\end{array}$ & $\begin{array}{c}\text { Alpha's } \\
\text { Cronbach }\end{array}$ \\
\hline \multirow{30}{*}{ Quality } & \multirow{6}{*}{$\begin{array}{l}\text { communication } \\
\text { channels }\end{array}$} & ATMs are trusted. & 0.37 & \multirow{6}{*}{0.854} \\
\hline & & I can fix some of my bank's needs through ATM. & 0.34 & \\
\hline & & Internet Banking makes my interaction easier. & 0.56 & \\
\hline & & $\begin{array}{l}\text { Internet banking provides the right service to meet } \\
\text { my needs... }\end{array}$ & 0.60 & \\
\hline & & $\begin{array}{l}\text { It is understandable for me to learn about the new } \\
\text { bank services through the bank's website. }\end{array}$ & 0.43 & \\
\hline & & My bank offers me decent services. & 0.32 & \\
\hline & \multirow{6}{*}{$\begin{array}{l}\text { the overall } \\
\text { quality of } \\
\text { communication }\end{array}$} & My bank timely fulfills its promises & 0.49 & \multirow{6}{*}{0.808} \\
\hline & & $\begin{array}{l}\text { My bank systems allow me to fulfill my bank's } \\
\text { needs. }\end{array}$ & 0.65 & \\
\hline & & The bank hours are appropriate for me. & 0.39 & \\
\hline & & $\begin{array}{l}\text { I prefer to spend most of my monthly bankroll } \\
\text { through e-channels like (Internet, email, web, } \\
\text { mobile, phone, ATM). }\end{array}$ & 0.66 & \\
\hline & & $\begin{array}{l}\text { There is evidence that the bank's website security } \\
\text { is sufficient. }\end{array}$ & 0.50 & \\
\hline & & $\begin{array}{l}\text { There is a possibility to communicate and ask } \\
\text { questions and requests via e-mail. }\end{array}$ & 0.54 & \\
\hline & \multirow{7}{*}{ confidence } & I get services from the bank through the mobile. & 0.42 & \multirow{7}{*}{0.650} \\
\hline & & Using services through the mobile is easy. & 0.46 & \\
\hline & & $\begin{array}{l}\text { My bank is conducting regular customer } \\
\text { evaluations of information provided on the quality } \\
\text { of services and the actual performance of the } \\
\text { services provided. }\end{array}$ & 0.52 & \\
\hline & & $\begin{array}{l}\text { The quality of the equipment and services of the } \\
\text { bank will lead to a sense of security in the } \\
\text { transactions. }\end{array}$ & 0.65 & \\
\hline & & $\begin{array}{l}\text { Delivering services at reasonable cost, but not by } \\
\text { reducing quality. }\end{array}$ & 0.52 & \\
\hline & & $\begin{array}{l}\text { The presence of employees who have the } \\
\text { knowledge and competence necessary to meet } \\
\text { customer specific requests. }\end{array}$ & 0.46 & \\
\hline & & $\begin{array}{l}\text { Paying attention to individual customers through } \\
\text { their best interests. }\end{array}$ & 0.57 & \\
\hline & \multirow{6}{*}{ satisfaction } & $\begin{array}{l}\text { Existence of employees who understand the needs } \\
\text { of customers. }\end{array}$ & 0.77 & \multirow{6}{*}{0.752} \\
\hline & & $\begin{array}{l}\text { In general, I am satisfied with the relationship and } \\
\text { quality of my bank services. }\end{array}$ & 0.46 & \\
\hline & & I am satisfied with how this bank operates. & 0.75 & \\
\hline & & $\begin{array}{l}\text { I feel that the way the bank treats situations and } \\
\text { situations is in line with my demands. }\end{array}$ & 0.75 & \\
\hline & & $\begin{array}{l}\text { I think I made the right decision using an online } \\
\text { banking system and technology channels. }\end{array}$ & 0.36 & \\
\hline & & $\begin{array}{l}\text { In general, I am happy with my electronic banking } \\
\text { channels. }\end{array}$ & 0.86 & \\
\hline & \multirow{5}{*}{ loyalty } & $\begin{array}{l}\text { The bank uses the latest technology to carry out } \\
\text { banking business. }\end{array}$ & 0.71 & \multirow{5}{*}{0.808} \\
\hline & & The bank is targeting customer satisfaction. & 0.75 & \\
\hline & & $\begin{array}{l}\text { The employees of the bank see continuous training } \\
\text { for providing good services. }\end{array}$ & 0.50 & \\
\hline & & The bank acts in accordance with its obligations. & 0.46 & \\
\hline & & $\begin{array}{l}\text { The bank is generally committed to providing } \\
\text { appropriate customer service. }\end{array}$ & 0.60 & \\
\hline
\end{tabular}




\begin{tabular}{|c|c|c|c|c|}
\hline dimensions & variable & Item & $\begin{array}{l}\text { Factor } \\
\text { loading }\end{array}$ & $\begin{array}{l}\text { Alpha's } \\
\text { Cronbach }\end{array}$ \\
\hline & \multirow{5}{*}{ maintenance } & $\begin{array}{l}\text { I feel with my personal information that I can trust } \\
\text { my bank. }\end{array}$ & 0.37 & \multirow{5}{*}{0.873} \\
\hline & & $\begin{array}{l}\text { The behavior of the staff of this bank has created } \\
\text { trust in me. }\end{array}$ & 0.81 & \\
\hline & & This bank is a true bank. & 0.76 & \\
\hline & & I will work with the bank in the future. & 0.57 & \\
\hline & & I say something about this bank to others. & 0.63 & \\
\hline & \multirow{5}{*}{$\begin{array}{l}\text { the tendency to } \\
\text { compromise }\end{array}$} & $\begin{array}{l}\text { I encourage friends and relatives to invest in this } \\
\text { bank. }\end{array}$ & 0.56 & \multirow{5}{*}{0.850} \\
\hline & & In general, I am very pleased with this bank. & 0.58 & \\
\hline & & $\begin{array}{l}\text { The customer can order the requested service to } \\
\text { the bank. }\end{array}$ & 0.59 & \\
\hline & & $\begin{array}{l}\text { The time period between ordering and receiving } \\
\text { services is relatively short. }\end{array}$ & 0.49 & \\
\hline & & $\begin{array}{l}\text { Ordered service, with the same features as my } \\
\text { requested delivery. }\end{array}$ & 0.62 & \\
\hline
\end{tabular}

\section{4 .Findings}

In this study, hypothesis testing is performed using structural equation modeling using Lizrel software. One of the basic points in structural equation models, such as the measurement model (confirmatory factor analysis), is the fitting indices that can be relied upon and used when the model is appropriate. If the indexes of NFI, NNFI, and CFI are greater than 0.90 and RMSEA is less than 0.08 , then fitting the model is appropriate .

All eight of the research hypotheses have a proper fit and positive effect. In Figures 2 and 3, the results of the standard coefficients and the direction of the structural model of the research have been shown.

In Table 4, fit indices and Table 5 summarize the results of testing the main and secondary hypotheses along with the regression coefficient and the partial index values of each hypothesis.

Table (4): fitting indices for the Adjusted model

\begin{tabular}{|c|c|c|c|}
\hline Indicator & the amount & Acceptable limit & Result \\
\hline Relative Chi-Square (DF / $2 x)$ & 3.32 & Between 1 and 5 & Acceptable \\
\hline Normative Fitness Index (NFI) & 0.97 & Close to one & Acceptable \\
\hline Goodness of Fit Index (GFI) & 0.95 & Close to one & Acceptable \\
\hline Adjusted Goodness of Fit Index(AGFI) & 0.89 & Close to one & Acceptable \\
\hline Comparative Fit Index(CFI) & 0.98 & $0 / 9>$ & Acceptable \\
\hline Normative Fit Index (PNFI) & 0.59 & Above 50\% & Acceptable \\
\hline $\begin{array}{c}\text { Root Mean Square Error of Approximation } \\
\text { (RMSEA) }\end{array}$ & 0.060 & $0 / 08<$ & Acceptable \\
\hline
\end{tabular}




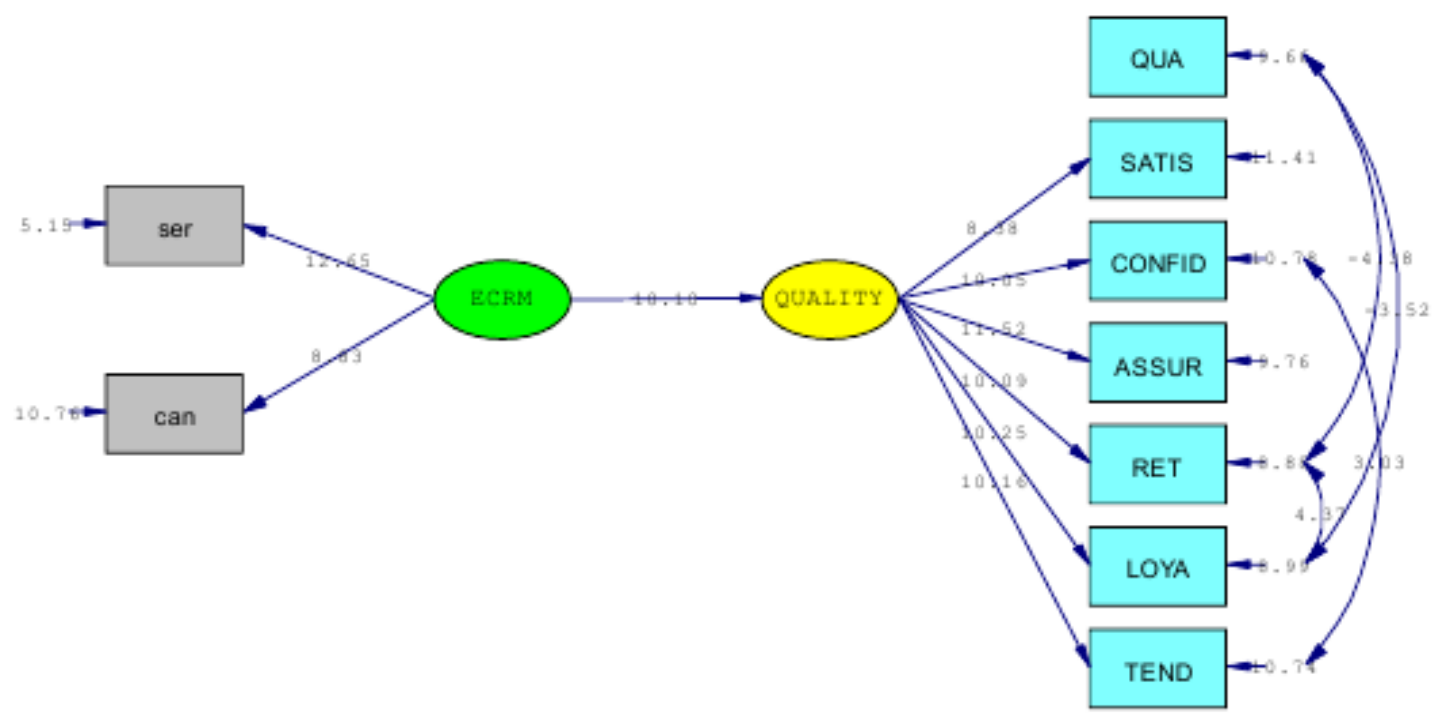

Chi-Square-73.11, df-22, P-value-0.00000, RMSEA-0.060

Figure (2): The standard coefficients of the modified structural model

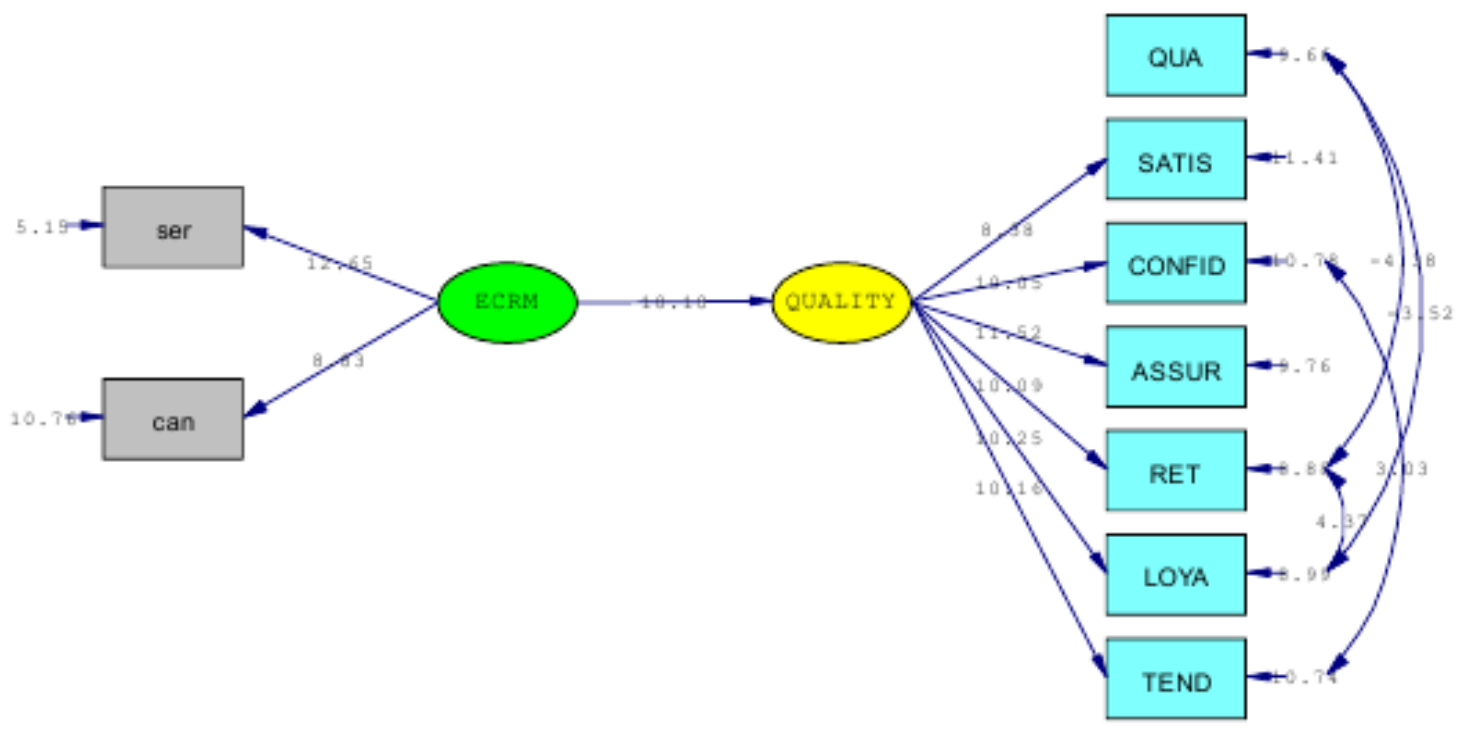

Chi-Square-73.11, de-22, P-value-0.00000, RMSEA-0.060

Figure (3): The coefficients of the modified structural model 
Table 5: Summary results of testing the main and the secondary hypotheses

\begin{tabular}{|c|c|c|c|c|c|}
\hline Analysis path & \multirow{2}{*}{$\begin{array}{c}\text { Standard } \\
\text { regression weight } \\
0.87\end{array}$} & \multirow{2}{*}{$\begin{array}{l}\text { Conformity } \\
\text { Critical ratio } \\
0.10\end{array}$} & \multicolumn{2}{|c|}{ criterion } & \multirow{2}{*}{$\begin{array}{c}\begin{array}{c}\text { Test } \\
\text { result }\end{array} \\
\text { Confirm }\end{array}$} \\
\hline $\begin{array}{l}\text { E-CRM } \Longrightarrow \text { Customer relationships } \\
\text { quality and the consequences }\end{array}$ & & & 10.10 & + & \\
\hline E-CRM $\Longrightarrow$ communication channels & 0.60 & 0.084 & 8.11 & + & Confirm \\
\hline $\begin{array}{l}\mathrm{E}-\mathrm{CRM} \rightleftharpoons \text { the overall quality of } \\
\text { communication }\end{array}$ & 0.95 & 0.10 & 9.28 & + & Confirm \\
\hline E-CRM $\Longrightarrow$ Customer confidence & 0.66 & 0.11 & 6.04 & + & Confirm \\
\hline E-CRM $\Longrightarrow$ Customer satisfaction & 0.55 & 0.23 & 2.42 & + & Confirm \\
\hline E-CRM $\Longrightarrow$ loyalty & 0.63 & 0.087 & 7.25 & + & Confirm \\
\hline E-CRM $\Longrightarrow$ customer Maintenance & 0.58 & 0.082 & 7.12 & + & Confirm \\
\hline $\begin{array}{l}\mathrm{E}-\mathrm{CRM} \rightleftharpoons \text { the tendency to } \\
\text { compromise }\end{array}$ & 0.87 & 0.86 & 6.90 & + & Confirm \\
\hline
\end{tabular}

\section{5. .DISCUSSION AND CONCLUSION:}

The main goal of this research is: the E-CRM on the relationships quality and it's consequences: evidence from Iranian the private banks, that the E-CRM in the Private Bank has a positive and significant relationship with the quality and consequence of customer relationships with the bank. The results of testing this hypothesis make it clear that the standard regression coefficient is 0.87 . Since the value of the T-statistic is greater than 1.96 , our hypothesis is confirmed; that is, the E-CRM in the Private Bank has a significant and significant impact on the quality and consequence of the customer relationship. This conclusion is consistent with the results of studies by Sivaraks, Krairit, Tang (2011).

The E-CRM in the Private Bank has a significant positive correlation with the customer communication channels with the bank. The results of this hypothesis test show that the standard regression coefficient is larger, so our hypothesis is confirmed; that is, E-CRM in the Private Bank has a significant and significant impact on the customer communication channels. This conclusion is consistent with the results of studies by Sivaraks, Krairit, Tang (2011).According to the results of the review of the first hypothesis, it seems that customer and customer orientation are needed in the eyes mortgages will be included in the Private Bank and workshops will be held to train "continuous customer relations" for employees and managers of the bank. In electronic devices, customer relationship management, chat services and forum development for customers who have questions or problems regarding electronic banking operations; therefore, a list of common questions frequently asked by customers is required. Be prepared and included with the answer on the site. The most commonly asked questions should be made available to the customer as a matter of urgency so that they can select the subject from the list if necessary. Additionally, you should always have a direct link to the linked page.

The E-CRM in the Private Bank has a significant positive correlation with the overall quality of customer relationships with the bank. The results of testing this hypothesis make it clear that the standard regression coefficient is bigger, so our hypothesis is confirmed; that is, the management of communication with electronic customers at Bank Private Bank has a significant and significant impact on the overall customer quality. This conclusion is consistent with the results of studies by Sivaraks, Krairit, Tang (2011). A similar study by Abdulfattah (2012) investigated the effects of various e-CRM features at different stages of the transaction cycle, on customer satisfaction on banks' websites. The aforementioned researcher also established that e-CRM influences customer relationships and enhances online customer satisfaction and service quality.

According to the results, the banking system should provide the services needed by the current community in line with the market structure and provide acceleration of growth and economic well-being of the country. In this way, it is important to examine the factors affecting the overall quality of customer relationship; therefore, considering the importance of the overall quality of customer relationship, bank managers must understand the implementation of e-CRM and, consequently, the overall quality of customer relationship as a profit factor and pay attention to this.

The E-CRM in the Private Bank has a significant positive relationship with customer confidence. The results of testing this hypothesis make it clear that the standard regression coefficient is bigger, so our hypothesis is confirmed; that is, the E-CRM in the Private Bank has a significant and significant effect on customer confidence. This is consistent with the results of the studies by Sivaraks, Krairit, Tang (2011). Considering the results of the third hypothesis on the security features used in conducting banking operations, it should be informed in a part of the bank's electronic tools in order to increase the trust and confidence of the customers.. Also, the bank can guarantee in its terms and conditions of using its electronic banking that, in case of non-compliance with the privacy of customer accounts, it will pay damages to increase the customer's confidence in this way.

The E-CRM in the Private Bank has a significant positive relationship with customer satisfaction. The results 
of testing this hypothesis make it clear that the standard regression coefficient is bigger, so our hypothesis is confirmed; the E-CRM in the Private Bank has a significant and significant effect on customer satisfaction. This conclusion is consistent with the results of the studies by Sivaraks, Krairit, Tang (2011). while Alim and Ozuem (2014) concluded that E-CRM is effective in strengthening relationships with customers and promoting the development of an attractive virtual community, which further enhances satisfaction.

According to the results, the banking system, customers should consider themselves valuable assets and ask all their subsystems to use their best endeavors to satisfy customers because the likelihood of repeating and verifying the type of service by a loyal customer is satisfactory. It is therefore wise for the bank to regularly assess and evaluate the customer satisfaction from their point of view.

The E-CRM in the Private Bank has a significant positive correlation with customer loyalty. The results of this hypothesis test have made it clear that the standard regression coefficient is bigger, so our hypothesis is confirmed; that is, the E-CRM in the Private Bank has a significant and significant effect on customer loyalty. This conclusion is consistent with the results of the studies by Sivaraks, Krairit, Tang (2011).

Alhaiou (2011) who studied the relationship between e-CRM features and e-loyalty on online shoppers at the different stages of transaction cycle argued that the use of e-CRM in building consumer relationships affects online consumer satisfaction and loyalty, Rabbai (2013) confirmed the effect of e-CRM on customer loyalty.

According to the results, in the banking system, customers are the main focus, and in fact all the work is to attract satisfaction and attraction; therefore, in the competitive environment between banks, banks are more successful, which can be more loyal to customers. On the other hand, in view of the customers becoming more sensitive to the provision of services by banks, they always want to provide better and better service. Ultimately, if the banking system wants to establish loyalty to customers, then it is necessary to maintain the customer's responsibility as its most important task. The banking system must consider its customers valuable assets and ask all its subsystems to use their best efforts to attract, maintain and loyal customers, since the likelihood of repeating and verifying the type of service by the customer is loyal to the customer; It is wise for the bank to regularly evaluate and evaluate the customer loyalty from their point of view.

The E-CRM in the Private Bank has a significant positive correlation with customer retention. The results of testing this hypothesis make it clear that the standard regression coefficient is bigger, so our hypothesis is confirmed; that is, the E-CRM in the Private Bank has a significant and significant effect on customer retention. This conclusion is consistent with the results of the studies by Sivaraks, Krairit, Tang, (2011) and Tanveer (2009). Considering the results of the sixth hypothesis, finally, if a banking system wants to establish customer loyalty, then it should be the duty of customer preservation to be considered as its most important task. The banking system must consider its customers valuable assets and ask all its subsystems to use their best efforts to attract, maintain and loyal customers, since the likelihood of repeating and verifying the type of service by the customer is loyal to the customer; It is wise to regularly assess and evaluate the bank's healthy banking competition in their own way.

The E-CRM in the Private Bank has a significant positive correlation with the willingness to compromise. The results of testing this hypothesis make it clear that the standard regression coefficient is bigger, so the hypothesis is confirmed; that is, the E-CRM in the Private Bank has a significant and significant effect on the willingness to compromise. This conclusion is consistent with the results of the study by Sivarax, Curarite and Tang (2011). According to the results of the review, time and speed in the relationship between e-bank and customer, an important issue is that the bank should work towards improving this feature. The bank constantly updates its software and hardware equipment, so that it can always serve customers at higher speeds, otherwise the risk of loss of customers will increase. In response to customer issues, it is imperative that e-mails be answered promptly so that customers believe that follow-up authorities are their issues.

\section{Executive Suggestions}

The findings of this study have interesting implications for the role of information technology manager, public relations and senior marketing manager of the bank. In the analytical review, the findings of this study resulted in the following recommendations :

1. The management of technology and information and public relations management of the bank should pay particular attention to the more precise design of the website of the bank. Therefore, it is possible to quickly and without the need for additional effort to use internet banking services. Different stages of Internet banking and customer relationship management, It must be designed in such a way that after each step, the user can easily and easily lead the next step. Whatever, It is easier to use the system, it accepts and communicates more easily and benefits its users. In fact, a step-by-step guide to using electronic and Internet services and increasing the number of e-customers requires the creation of culture through both the electronic channels and the bank's website, as well as through the bank's promotional and educational brochures available to customers, and most importantly Learning and transferring it through partners at Private Bank Branches can help to manage communication with electronic customers.

The government can also provide assistance by providing the necessary facilities to provide better electronic and 
Internet services at the right speed.

Also, the findings of this study for senior management of bank marketing, emphasize more on personalization, technologies Direct marketing is for sale and provides distinct services to the small and large market segments. This is important and possible in E-CRM, but more attention is needed to this specific issue. Where both the bank and the client benefit this relationship. In this regard, empowering customers, enhancing multichannel communication and interactivity One-to-one mortgaging and paying attention to specific segments of the market that are relevant to bank activities can be very effective.

The research results confirm the impact and importance of customer relationship management on satisfaction, loyalty and customer retention. Given the increasing competition in the banking sector and the need for more customer attention in the bank, it is recommended that the bank Develop and implement a comprehensive and integrated program for customer relationship management.

\section{Research Limitations:}

In general, any research is subject to limitations that resolve it, affecting the accuracy of the research. Our research limitations are as follows:

1.Any scientific research is subject to limitations. The researcher can not study the whole community due to time constraints, cost, and manpower. Also, because research is conducted in a limited time period, the behavior of the sample is measured only at that time.

2. Other limitations of the research can be the limitations of collecting research data using a questionnaire. Limitations like: Constraint indispensability of written questionnaires, impossibility to fully assess the accuracy of respondents, unwillingness of some respondents to cooperate.

3 .Lack of access to library resources due to the limited resources available in campuses.

4. Not generalizability of results to other organizations.

\section{Suggestions for future research}

Considering the issues that the researcher encountered in the research, the following topics are suggested for future studies:

1 .The study of the problems and obstacles leading to the implementation of the E-CRM in different parts of the Private Bank and a solution to solve it.

2 .Performing a similar study in other banks and comparing their findings and results.

3 .This research focused on the field of electronic customer relationship management in the banking industry, it is suggested that this research be done in other service industries such as the insurance industry, hotel industry, etc.

4. The study population of this reseaech was bank customers. In this study, the electronic customer relationship management and customer satisfaction was investigated. Therefore, it is suggested that in future studies, the attitude of managers and employees of the bank towards the electronic customer relationship management should be considered.

\section{Reference}

[1] Abdallah Q. Bataineh (2015). "The Effect of E-CRM Practices on eWOM on Banks' SNSs: The Mediating Role of Customer Satisfaction. " International Business Research; Vol. 8, No. 5.

[2] Abdulfattah, F. H. (2012). "The effect of electronic customer relationship on customer satisfaction a study on web banking in Saudi Arabia. " Unpublished PhD Thesis, University of Huddersfield, West Yorkshire, England. Retrieved 12 June 2016 from http://eprints.hud.ac.uk/id/eprint/18098/.

[3] Alagheband, B., (2006) ). "Adoption of Electronic Banking Services by Iranian Customers", Ph.D., Tarbiat Modares University.

[4] Al-Badawi, Amir. Regarding ethnicity, M. (2014). "Customer relationship management in electronic environment. " International Conference.

[5] Alhaiou, T. A. (2011). "A Study on the Relationship between e-CRM Features and E-Loyalty: the case in UK. " Unpublished PhD thesis, Brunel Business School, Brunel University, West London. Retrieved 24 April 2016 from http://www.core.ac.uk/download/pdf/1440953.pdf

[6] Alim, S., and Ozuem, W. (2014). " The influences of e-CRM on customer satisfaction and loyalty in the UK mobile industry. " Journal of Applied Business and Finance Researches, 3(2), 47-54.

[7] Anton, J., \& Hoeck, M. (2002). "E-Business customer service. "Santa Monica, CA: Anton

[8] Assouad, A., and Overby, J. (2016). "The impact of culture on customer expectations. "Journal of Management Policy and Practice, 17(2), 19-32.

[9] Azila, N., and Noor, M. (2011). " Electronic customer relationship management performance: its impact on loyalty from customers' perspectives. "International Journal of e-Education, e-Business, e-Management and e-Learning, 1(1), 1-6. 
[10] Barnes, J. G. (2001). "Secrets of customer relationship management: It's all about how you make them feel. " New York, NY: McGraw-Hill.

[11] Bradshaw, D., \& Brash, C. (2001). "Managing customer relationships in the e-business world: How to personalize computer relationships for increased profitability. "

[12] Brown, S. A. (2000). " Customer relationship management: A strategic imperative in the world of E-business. "Toronto, Canada: John Wiley \& Sons.

[13] Chalmeta, R. (2006). "Methodology for customer relationship management. "Journal of Systems and Software, 79, 1015-1024.

[14] Chess Media Group, and Lieberman, M. (2010). " Guide to understanding social CRM. " Chess Media Group. Retrieved28March,2017fromhttp://www.sales20conf.com/SF2012/PDFs/Guide_to_Understanding_Social_ CRM.pdf

[15] Colgate, M., \& Hedge, R. (2001). "An investigation into the switching process in retail banking services. " International Journal of Bank Marketing, 19(5), 201-212.

[16] Dubihlela, J., and Khosa, P. M. (2014). " Impact of e-CRM implementation on customer loyalty, customer retention and customer profitability for hoteliers along the Vaal Meander of South Africa. " Mediterranean Journal of Social Sciences, 5(16), 175-183. http://dx.doi.org/10.5901/mjss.2014.v5n16p175.

[17] Dyche, J. (2001). "The CRM handbook: A business guide to customer relationship management. " Boston: Addison-Wesley.

[18] Eric E, Mang'unyi, Oumar T. Khabala and Krishna K. Govender (2017). "The relationship between e-CRM and customer loyalty: a Kenyan Commercial Bank case study. "Banks and Bank Systems journal, 12(2), 106115.

[19] Elahi and Heidari (2005). "Customer Relationship Management, Tehran, Publication, Trading and Distribution Company. "

[20] Feinberg, R., \& Kadam, R. (2002). " E-CRM Web service attributes as determinants of customer satisfaction with retail Web sites. " International Journal of Service Industry Management, 13(5), 432-451.

[21] Foss, B., \& Slone, M. (2002). " CRM in financial services: A practical guide to making customer relationship management work. " : Kogan Page August.

[22] George K. Amoako*, Emmanuel Arthur, Christiana Bandoh and Rachel Kafui Katah (2011). " The impact of effective customer relationship management (CRM) on repurchase: A case study of (GOLDEN TULIP) hotel (ACCRA-GHANA). " African Journal of Marketing Management Vol. 4(1), pp. 17-29.

[23] Gounaris, S. P., Stathakopoulos, V., \& Athanassopoulos, A. D. (2003). " Antecedents to perceived service quality: an exploratory study in the banking industry. " International journal of bank marketing, 21(4), 168190.

[24] Greenberg, Paul (2001). "CRM at the speed of light. Berkeley. " CA: Osborne/McGraw-Hill.

[25] Grönroons, C. (1990). "Service management and marketing: Managing the moments of trust in service competition. " Lexington, MA: Lexington Books.

[26] Gupta, S. and Mittal, A. (2013). " Emerging role of information technology in banking sector's development of India. " Acme International Journal of Multidisciplinary Research, Vol. 1, pp.61-65.

[27] Harrigan, P., Ramsey, E., and Ibbotson, P. (2012). " Entrepreneurial marketing in SMEs: the key capabilities of E-CRM. " Journal of Research in Marketing and Entrepreneurship, 14(1), 40-64.

[28] Harrigan, P., Ramsey, E., and Ibbotson, P. (2008). " E-CRM in SMEs: An exploratory study in Northern Ireland. " Marketing Intelligence and Planning, 26(4), 385-404.

[29] Hennig-Thurau, T., \& Klee, A. (1997). "The impact of customer satisfaction and relationship quality on customer retention: A critical reassessment and model development. " Psychology and Marketing, 14(18), 737-764.

[30] Jackson, B. B. (1985). "Winning and keeping industrial customers: The dynamics of customer relationships. " Lexington, MA: D.C. Heath.

[31] Keshvari, R. S. (2012). " The impact of E-CRM on customers attitude and its association with generating competitive advantages in Iranian financial B2B context. " International Business Research, 5(4), 34-54. http://dx.doi.org/10.5539/ibr.v5n4p34.

[32] Khalifa, M., \& Shen, N. (2005). " Effects of Electronic Customer Relationship Management on customer satisfaction: A temporal model. " Proceedings of the 38th Hawaii International Conference on System Sciences.

[33] Kim-Soon, N., and Zulkifli, M. F. (2012). "The impact of electronic customer relationship management (ECRM) on the business performance of small company. " Journal of Engineering and Technology, 3(12), 139153.

[34] Kotler,P. \& Keller, K. L. (2014). Marketing Management; 12 th Edition. New Jersy: Prentice Hall. PP.52.\& PP.40

[35] Lam, A. Y. C., Cheung, R., and Lau, M. (2013). "The influence of internet-based customer relationship 
management on customer loyalty. " Contemporary Management Research, 9(4), 419-440. http://dx.doi.org/10.7903/cmr.11095.

[36] Lindgreen, A., \& Antioco, M. (2005). "Customer relationship management: The case of a European bank. " Marketing Intelligence \& Planning, 23, 136-154.

[37] Moezizi, H. (2012). "Correlation between the determinants of electronic customer relationship management system (E-CRM) and customer satisfaction in Golsar Fars sanity", MSc Thesis, University of Sistan and Balochistan.

[38] Moussa Khani, M., and Shams, Raheil (2006). "E-Customer Relationship Management: Communication Bridge of Business and Information Technology. " Management Perspective, No. 19 \& 20.

[39] Mousavian,S., Jalili Ghasbeh, M. (2017). "Investigation of Relationship between E-Banking Industry Risks and Electronic Customer Relationship Management (E-CRM). " MAYFEB Journal of Business and Management - ISSN 2371-7742 Vol 2 (2017) - Pages 26-34.

[40] Rabbai, R. A. (2013). " Investigating the impact of e-CRM on customer loyalty: a case of B2B in Zain company in Jordan. " Unpublished Master in E-Business thesis, Business Administration Faculty, Middle East University, Jordan. Retrieved 5 May 2016 from https://meu.edu.jo/uploads/1/58749ce6546b1_1.pdf.

[41] Rahman, Z. (2006). "Customer experience management: A case study of an Indian bank. " Journal of Database Marketing and Customer Strategy Management, 13(3), 203-221.

[42] Rashid, F., Khalid, R. (2017). " Effectiveness of e-CRM in Commercial Banks: Banker’s Perspective. " Asian J. Management; 8(2):293-304.

[43] Roloff, M. E., \& Miller, G. R. (1987). "Interpersonal processes: New directions in communication research. " London: Sage.

[44] Salehi, S., Kheyrmand, M., and Faraghian, H. (2015). "Evaluation of the effects of e-CRM on customer loyalty (Case Study: Esfahan branches of Sepah Bank). " Paper presented at the 9th International Conference on ecommerce with focus on e-business on 16th April, 2015, Isfahan, Iran, 1-8. Retrieved from http://www.ecdcconference.org

[45] Singh, S. and Sirohi, N. (2014). " Internet banking services as tool of CRM: a study of customer satisfaction in the national capital region, Delhi. " International Journal of Electronic Customer Relationship Management, Vol. 8, Nos. 1-3, pp.101-118.

[46] Singh, S., Chhatwal, S. S., Yahyabhoy, T. M., \& Yeo, C. H. (2002). " Dynamics of innovation in E-banking. " ECISPoland: Gdansk June 6-8.

[47] Sivaraks, Phavaphan; Krairit, Donyaprueth, Tang, John (2011). " Effects of e-CRM on customer-bank relationship quality and outcomes: The case of Thailand. " journal of high technology management, research22.141-157.

[48] Soltani, F. (2003), "CRM and E-CRM Understanding Customer Relationship Management "article, Norwegian Specialist Magazines, Tomorrow's Management Magazine, 57-66.

[49] Storbacka, K., Strandvik, T., \& Grönroos, C. (1994). " Managing customer relationships for profit: the dynamics of relationship quality. " International journal of service industry management, 5(5), 21-38.

[50] Swift, R. S. (2001). " Accelerating customer relationships using CRM and relationship technologies. " Upper Saddle River, NJ: Prentice-Hall PTR.

[51] Tanveer, A. (2009). " Electronic customer relationship management in online banking. " Unpublished Master's thesis, Luleå University of Technology, Sweden. Retrieved 24 April 2016 from www.divaportal.org/smash/get/diva2:1018049/FULLTEXT01.pdf.

[52] Zareyan, M., (2009), "Investigating the Role of Information Technology in the Establishment of E-CRM", Yazd University.

[53] Yun, Z., and Good, L. K. (2007). "Developing customer loyalty from e-tail store image attributes. Managing Service Quality. " An International Journal, 17(1), 4-22.

[54] Zeithaml, V. A. (1981). " How consumer evaluation processes differ between goods and services. " In J. H. Donnelly \& W.R. George (Eds.), Marketing of Services (pp. 186-190). Chicago, IL: American Marketing Association. 